\title{
Changes in Conformation and Subcellular Distribution of $\alpha 4 \beta 2$ Nicotinic Acetylcholine Receptors Revealed by Chronic Nicotine Treatment and Expression of Subunit Chimeras
}

\author{
Patricia C. Harkness and Neil S. Millar \\ Department of Pharmacology, University College London, London, WC1E 6BT, United Kingdom
}

\begin{abstract}
Chronic exposure to nicotine, as occurs during tobacco smoking, is one of several factors that have been reported to cause an upregulation of neuronal nicotinic acetylcholine receptors (nAChRs). Here, the influence of both chronic exposure to nicotine (10 $\mu \mathrm{M}, 24 \mathrm{hr}$ ) and the coexpression of subunit chimeras has been examined in cultured cell lines expressing recombinant $\alpha 4 \beta 2$ nAChRs, a major nicotinic receptor subtype expressed in the mammalian brain. Evidence is presented which demonstrates that both chronic exposure to nicotine and the coexpression of subunit chimeras upregulates levels of receptor expressed on the cell surface. Immunoblotting data indicate that neither chronic nicotine treatment nor coexpressed subunit partners greatly affect the level of total subunit protein. This finding, together with radioligand and antibody binding studies conducted on both intact and permeabilized cells, reveals that receptor upregulation corresponds to an increase in the pro-
\end{abstract}

Chronic exposure to nicotine, as occurs during tobacco smoking, has been widely reported to cause an upregulation of nicotinic acetylcholine receptors (nAChRs) in the brain. This has been demonstrated as an increase in the density of nicotinic radioligand binding sites both in postmortem human brain tissue of smokers (Benwell et al., 1988) and in the brains of animals after chronic exposure to nicotine (Marks et al., 1985, 1992; Schwartz and Kellar, 1985).

A major subtype of nAChRs expressed in mammalian brain contains the $\alpha 4$ and $\beta 2$ subunits, and brain nAChRs coassembled from these subunits have been shown to be upregulated by chronic nicotine exposure (Flores et al., 1992). Several studies have reported a similar upregulation of nicotinic radioligand binding sites and cell-surface receptor levels in heterologous expression systems expressing recombinant $\alpha 4 \beta 2 \mathrm{nAChRs}$ after chronic exposure to nicotine (Peng et al., 1994; Zhang et al., 1994; Bencherif et al., 1995; Gopalakrishnan et al., 1996, 1997; Rothhut et al., 1996; Warpman et al., 1998; Whiteaker et al., 1998). It appears, however, that not all nAChR subtypes are upregulated to the same extent by chronic exposure to nicotine (Peng et al., 1997; Ke et al., 1998; Wang et al., 1998). The mechanisms underlying nicotine-induced upregulation of nAChRs are still unclear,

Received April 22, 2002; revised July 26, 2002; accepted Sept. 24, 2002.

This work was supported by grants from the Wellcome Trust. We thank Harriet Sale and Shehan Wevita for assistance with some experiments and Dr. Ian Parsons for construction of pRK5- $\beta 2^{\mathrm{FLAG}}$

Correspondence should be addressed to Dr. Neil S. Millar, Department of Pharmacology, University College London, Gower Street, London, WC1E 6BT, UK. E-mail: n.millar@ucl.ac.uk.

Copyright (๑) 2002 Society for Neuroscience $0270-6474 / 02 / 2210172-10 \$ 15.00 / 0$ portion of total receptor expressed on the cell surface. It is also apparent that nicotine-induced $\mathrm{nAChR}$ upregulation is very strongly dependent on subunit composition and subunit domains. An important aspect of this study is that direct evidence has been obtained indicating that both chronic exposure to nicotine and coexpressed subunit partners can influence subunit conformation. The influence of chronic nicotine treatment on subunit folding may help to explain the phenomenon of nicotine-induced receptor upregulation. The finding that subunit conformation can be influenced by coassembled subunit partners is in agreement with models of receptor assembly which propose that subunit folding continues after initial subunit-subunit interactions.

Key words: nicotinic; acetylcholine receptor; folding; conformation; assembly; chimera but it is now generally accepted that this phenomenon, both in the brain and in heterologous expression systems, can be explained by post-transcriptional events (Marks et al., 1992; Peng et al., 1994; Zhang et al., 1994; Bencherif et al., 1995).

Heterologous expression of $\alpha 4 \beta 2 \mathrm{nAChRs}$ (and other $\mathrm{nAChR}$ subunits) frequently results in expression of only low levels of both nicotinic agonist binding sites and functional cell-surface receptors (Cooper and Millar, 1997, 1998; Kassner and Berg, 1997; Chen et al., 1998; Cooper et al., 1999; Sweileh et al., 2000). This has led to the conclusion that folding and assembly of neuronal nAChRs, in at least some host cell types, is a relatively inefficient process. Interestingly, very much higher levels of assembled cell-surface receptor can be generated by expressing chimeric subunits containing the extracellular domain of neuronal nAChR subunits fused to the transmembrane and intracellular region of the 5-hydroxytryptamine receptor 5- $\mathrm{HT}_{3 \mathrm{~A}}$ subunit (Eiselé et al., 1993; Rangwala et al., 1997; Cooper et al., 1999). For example, coexpression of the $\mathrm{nAChR} \beta 2$ subunit with an $\alpha 4-5 \mathrm{HT}_{3 \mathrm{~A}}$ subunit chimera $(\alpha 4 \chi)$ results in an increase (of $\sim 20$ fold) in the amount of $\beta 2$ expressed on the cell surface and in the level of nicotinic radioligand binding sites (Cooper et al., 1999).

In this study, the effect of chronic nicotine treatment both on $\alpha 4 \beta 2$ nAChRs and on receptors assembled from chimeric subunits has been examined. The proportion of total subunit protein expressed on the cell surface and the proportion of radioligand binding sites on the cell surface have been examined. This has revealed changes in subunit conformation and distribution attributable to chronic nicotine treatment and as a consequence of coexpression of subunit chimeras. 


\section{MATERIALS AND METHODS}

Materials. Rat neuronal nAChR $\alpha 4$ and $\beta 2$ subunit cDNAs (Goldman et al., 1987; Deneris et al., 1988) were provided by Dr. Jim Patrick (Baylor College of Medicine). The mouse 5 $\mathrm{HT}_{3 \mathrm{~A}}$ cDNA (Maricq et al., 1991) was provided by Dr. David Julius (University of California San Francisco). Chimeric nicotinic/serotonergic subunit cDNA constructs pRK5- $\alpha 4$ / $5 \mathrm{HT}_{3 \mathrm{~A}}$ and $\mathrm{pRK} 5-\beta 2 / 5 \mathrm{HT}_{3 \mathrm{~A}}$ (also referred to here as pRK5- $\alpha 4 \chi$ and pRK5- $\beta 2 \chi$, respectively) have been described previously (Cooper et al., 1999). All subunit cDNAs were subcloned into plasmid expression vector pRK5, as described previously (Cooper et al., 1999). An eight amino acid "FLAG" epitope-tag (Hopp et al., 1988) was introduced into the $\beta 2$ cDNA at a position immediately after the predicted signal sequence cleavage site of the $\beta 2$ subunit to create pRK5- $\beta 2^{\mathrm{FLAG}}$. Monoclonal antibody (mAb) 270, which recognizes an extracellular epitope on the nAChR $\beta 2$ subunit (Whiting and Lindstrom, 1987), was purified from the hybridoma cell line HB189 (obtained from the American Type Culture Collection, Rockville, MD). mAb299, which recognizes an extracellular epitope on the nAChR $\alpha 4$ subunit (Whiting and Lindstrom, 1988), was obtained from Sigma (Poole, UK). A polyclonal antiserum ( $\left.\mathrm{pAb} 5 \mathrm{HT}_{3}\right)$, raised against a fusion protein containing the intracellular loop region of the mouse $5 \mathrm{HT}_{3 \mathrm{~A}}$ receptor subunit (Turton et al., 1993), was provided by Dr. Ruth McKernan (Merck Sharp and Dohme Research Laboratories, Harlow, UK). A polyclonal antiserum (pAb120) raised against the extracellular region of the mouse $5 \mathrm{HT}_{3 \mathrm{~A}}$ receptor subunit (Spier et al., 1999) was obtained from Dr. Sarah Lummis (University of Cambridge). TSA201 cells, a derivative of the human embryonic kidney 293 cell line that expresses the simian virus 40 large $\mathrm{T}$-antigen, were obtained from Dr. William Green (University of Chicago).

Cell culture and transfection. Cells were cultured in DMEM (Invitrogen) containing $2 \mathrm{~mm}$ L-glutamine plus $10 \%$ heat-inactivated fetal calf serum (Sigma), penicillin $(100 \mathrm{U} / \mathrm{ml})$, and streptomycin $(100 \mu \mathrm{g} / \mathrm{ml})$ and maintained in a humidified incubator containing $5 \% \mathrm{CO}_{2}$ at $37^{\circ} \mathrm{C}$. Plasmid DNA was introduced into human TSA201 cells using the Effectene reagent (Qiagen) according to the manufacturer's instructions. Cells were transfected overnight and assayed for expression $\sim 42-44 \mathrm{hr}$ after transfection. In all cases in which chronic exposure to nicotine was examined, nicotine $(10 \mu \mathrm{M})$ was added to the cell culture medium for 24 hr (18-20 hr after transfection).

Radioligand binding. Binding studies with $\left[{ }^{3} \mathrm{H}\right]$ epibatidine (NEN Life Science; specific activity $67 \mathrm{Ci} / \mathrm{mmol}$ ) or $\left[{ }^{3} \mathrm{H}\right] \mathrm{GR} 65630$ (NEN Life Science; specific activity $76 \mathrm{Ci} / \mathrm{mmol}$ ) were performed on cell membrane preparations as described previously (Lansdell et al., 1997). Binding studies with $\left[{ }^{3} \mathrm{H}\right]$ methylcarbamylcholine $\left(\left[{ }^{3} \mathrm{H}\right] \mathrm{MCC}\right)$ (Tocris Cookson; specific activity $80 \mathrm{Ci} / \mathrm{mmol}$ ) were used to determine the subcellular distribution of binding sites. Cells were harvested in isotonic saline (HBSS; Invitrogen), and binding was performed with intact cells in the presence of protease inhibitors $(0.25 \mathrm{~mm}$ phenylmethylsulfonyl fluoride and $10 \mu \mathrm{g} / \mathrm{ml}$ each of leupeptin, aprotinin, and pepstatin; Sigma). Aliquots of the cell suspension were centrifuged and frozen rapidly, thawed, and then disrupted by passage three times through a 21 gauge needle in the presence of protease inhibitors. Samples were incubated with radioligand $\left(\left[{ }^{3} \mathrm{H}\right]\right.$ epibatidine or $\left.\left[{ }^{3} \mathrm{H}\right] \mathrm{MCC}\right)$ for $2 \mathrm{hr}$ at $4{ }^{\circ} \mathrm{C}$, and nicotine $(2$ $\mathrm{mm}$ ) was used to define nonspecific binding. Samples were assayed by filtration onto Whatman $\mathrm{GF} / \mathrm{B}$ filters presoaked in $0.5 \%$ polyethylenimine followed by rapid washing (three washes completed within $<5 \mathrm{sec}$ ) using a Brandel cell harvester. Amounts of total cellular protein were determined by a Bio-Rad DC protein assay using BSA standards.

Enzyme-linked assay of cell-surface expression levels. Cell-surface antibody binding was assayed on cells grown on poly-L-lysine-coated glass coverslips, transfected, incubated in primary antibody, and fixed as described previously (Cooper et al., 1999). To measure total (cell surface and internal) antibody binding, fixed cells were exposed for $15 \mathrm{~min}$ to $0.1 \%$ Triton X-100. Coverslips were processed as above, but $0.1 \%$ Triton $\mathrm{X}-100$ was included in all incubation buffers and in buffer used for the first two washing steps. Antibody solutions contained, additionally, 5\% fetal calf serum. When surface and total antibody binding levels were compared, coverslips (with permeablized or intact cells) were fixed before addition of primary antibody and assayed in parallel. Additionally, lysine $(25 \mathrm{~mm})$ was added to buffers to reduce nonspecific binding. In all cases, coverslips were incubated with horseradish peroxidase-conjugated goat anti-rat IgG (Amersham Biosciences), goat anti-rabbit IgG (Pierce), or goat anti-mouse IgG (Pierce) and washed six times before incubation with $600 \mu \mathrm{l} 3,3^{\prime}, 5,5^{\prime}$-tetramethylbenzidine (Sigma) for $1 \mathrm{hr}$. The supernatant was transferred to a cuvette, and absorbance was determined at $655 \mathrm{~nm}$.
Immunoblotting. At 18-20 hr after transfection, cells were maintained in the absence or presence of nicotine $(10 \mu \mathrm{M})$ for $24 \mathrm{hr}$. Cells were rinsed twice and harvested in isotonic saline, pelleted, and snap-frozen. Cell pellets were thawed on ice in the presence of protease inhibitors $(0.25 \mathrm{~mm}$ phenylmethylsulfonyl fluoride and $10 \mu \mathrm{g} / \mathrm{ml}$ each of leupeptin, aprotinin, and pepstatin; Sigma), and $150 \mu \mathrm{g}$ of total cellular protein was separated by $7.5 \%$ SDS-PAGE. Gels were equilibrated for $20 \mathrm{~min}$ in transfer buffer (25 mM Tris, $192 \mathrm{~mm}$ glycine, $20 \%$ methanol, $\mathrm{pH} 8.3$ ) and electroblotted onto Hybond-C nitrocellulose membranes (Amersham Biosciences). Membranes were blocked by incubation in PBS containing $0.1 \%$ Tween 20 and 5\% nonfat milk powder and then incubated with primary antibody in blocking solution for $2 \mathrm{hr}$ at room temperature. The membrane was washed thoroughly, incubated with an HRP-conjugated secondary antibody (goat anti-rat $\mathrm{IgG}$, goat anti-rabbit $\mathrm{IgG}$, or goat anti-mouse $\mathrm{IgG}$ ), and processed using the ECL detection system (Amersham Biosciences). Protein concentrations of cell pellets were determined by a Bio-Rad DC protein assay using BSA standards according to the manufacturer's instructions.

\section{RESULTS}

\section{Influence of nicotine and subunit composition on radioligand binding}

Specific high-affinity binding of the nicotinic radioligand $\left[{ }^{3} \mathrm{H}\right]$ epibatidine $\left(B_{\max }=0.15 \pm 0.04 \mathrm{pmol} / \mathrm{mg}\right.$ protein; $\left.n=8\right)$ was detected when mammalian kidney (TSA201) cells were cotransfected with rat $\mathrm{nAChR} \alpha 4$ and $\beta 2$ subunit cDNAs. This is consistent with previous reports showing that $\alpha 4$ and $\beta 2$ coassemble to generate a high-affinity agonist binding site and functional nAChRs when expressed in various mammalian cell lines (Whiting et al., 1991; Buisson et al., 1996; Ragozzino et al., 1997; Cooper et al., 1999). In agreement with our previously published findings (Cooper et al., 1999), significantly higher levels of radioligand binding sites were detected when either $\alpha 4$ or $\beta 2$ was coexpressed with $\mathrm{nAChR} / 5 \mathrm{HT}_{3} \mathrm{R}$ subunit chimeras $(\alpha 4 \chi$ or $\beta 2 \chi)$. Coexpression of $\alpha 4$ with $\beta 2 \chi$, rather than $\beta 2$, generated a significant increase $(4.5 \pm 0.5$-fold; $n=4 ; p<0.05)$ in radioligand binding sites (Fig. 1A). Similarly, coexpression of $\beta 2$ with $\alpha 4 \chi$, rather than $\alpha 4$, generated a significant increase (17.6 \pm 1.2 -fold; $n=4 ; p<0.001$ ) in total specific radioligand binding (Fig. 1A). As reported previously, none of these subunits forms an agonist binding site when expressed alone, but all of the pair-wise subunit combinations generate a high-affinity binding site for $\left[{ }^{3} \mathrm{H}\right]$ epibatidine that is not significantly different from that of $\alpha 4 \beta 2\left(K_{\mathrm{d}}=\right.$ $41 \pm 22 \mathrm{pm}$ ) (Cooper et al., 1999); thus, as discussed previously (Cooper et al., 1999), we conclude that this represents an increase in the proportion of $\alpha 4$ or $\beta 2$ subunits coassembling to generate correctly folded agonist binding sites when coexpressed with chimeric subunits.

Treatment of cells expressing $\alpha 4 \beta 2$ with nicotine (10 $\mu \mathrm{M}, 24 \mathrm{hr}$ ) resulted in an upregulation $(5.1 \pm 0.7$-fold; $n=4 ; p<0.001)$ in the level of specific $\left[{ }^{3} \mathrm{H}\right]$ epibatidine binding to cell homogenates (Fig. 1A). This is consistent with earlier studies which have demonstrated that treatment of cells expressing $\alpha 4 \beta 2$ with low concentrations of nicotine over relatively long periods (typically 1-100 $\mu \mathrm{M}$, for 24-48 hr) produces an upregulation of nicotinic radioligand binding sites by a post-transcriptional mechanism (Peng et al., 1994; Bencherif et al., 1995; Gopalakrishnan et al., 1996; Whiteaker et al., 1998). In parallel experiments, cells expressing subunit combinations $\alpha 4 \chi \beta 2$ or $\alpha 4 \beta 2 \chi$ were treated with nicotine $(10 \mu \mathrm{M}, 24 \mathrm{hr})$. The extent of nicotine-induced upregulation of radioligand binding in transfected cells was found to be influenced strongly by subunit composition (Fig. 1A). This has been emphasized by replotting the data to illustrate the level of radioligand binding in nicotine-treated cells relative to untreated cells (Fig. 1B). Chronic nicotine treatment produced a significant 

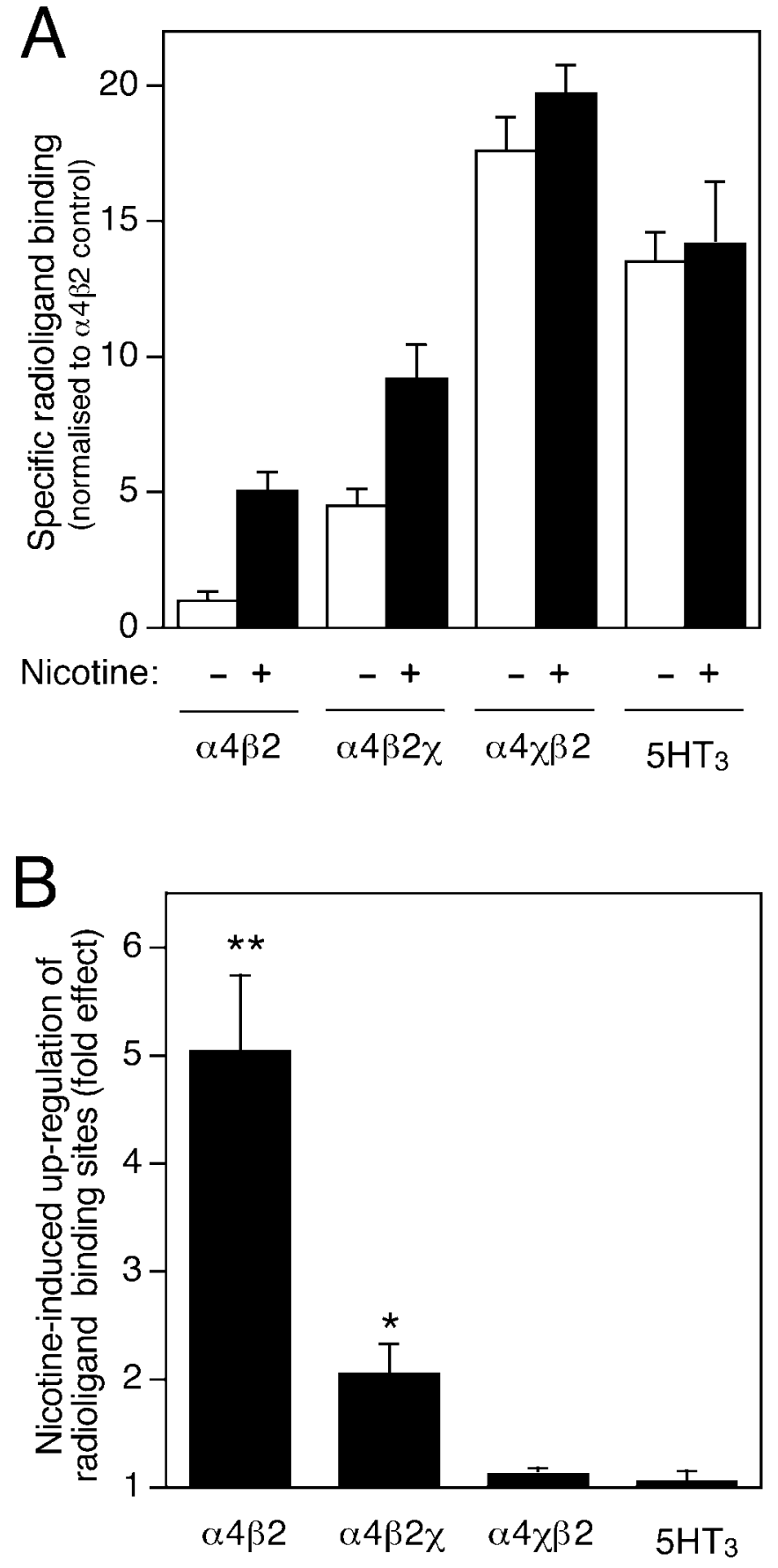

Figure 1. Influence of chronic nicotine treatment and subunit composition on radioligand binding to transfected TSA201 cells. A, Specific radioligand binding to cell homogenates from transfected cells was determined using a saturating concentration of $\left[{ }^{3} \mathrm{H}\right]$ epibatidine $(2 \mathrm{nM}$, for $\alpha 4 \beta 2, \alpha 4 \beta 2 \chi$, and $\alpha 4 \chi \beta 2)$ or $\left[{ }^{3} \mathrm{H}\right] \mathrm{GR}-65630$ (10 nM, for $\left.5 \mathrm{HT}_{3 \mathrm{~A}}\right)$. For all subunit combinations $\left(\alpha 4 \beta 2, \alpha 4 \beta 2 \chi, \alpha 4 \chi \beta 2\right.$, and $\left.5 \mathrm{HT}_{3 \mathrm{~A}}\right)$, radioligand binding was determined in cells that had been grown in the absence (white bars) or presence (black bars) of nicotine $(10 \mu \mathrm{M}, 24 \mathrm{hr})$. Data represent means \pm SEM of four independent experiments that have been normalized to the level of binding obtained with $\alpha 4 \beta 2$ in the absence of nicotine $(0.15 \pm 0.04 \mathrm{pmol} / \mathrm{mg}$ protein; $n=8)$. $B$, Data have been replotted to show the extent of nicotine-induced upregulation of radioligand binding for each subunit combination. Significant differences from control, determined by two-tailed Student's $t$ test, are indicated $\left({ }^{*} p<0.05\right.$; ${ }^{* *} p<$ 0.001). upregulation of radioligand binding with $\alpha 4 \beta 2 \chi(2.1 \pm 0.3$-fold; $n=4 ; p<0.05$ ) but did not cause a significant upregulation of binding to $\alpha 4 \chi \beta 2$. The concentration of nicotine used produces a maximal effect for all three subunit combinations (data not shown). As a control, the effect of chronic exposure to nicotine on the level of binding of the $5 \mathrm{HT}_{3} \mathrm{R}$ antagonist GR-65630 to cells transfected with the $5 \mathrm{HT}_{3 \mathrm{~A}}$ subunit was examined (Fig. 1). Incubation in $10 \mu \mathrm{M}$ nicotine for $24 \mathrm{hr}$ had no significant effect on the number of $\left[{ }^{3} \mathrm{H}\right] \mathrm{GR}-65630$ binding sites in cells expressing the $5 \mathrm{HT}_{3 \mathrm{~A}}$ subunit.

\section{Influence of nicotine and subunit composition on cell-surface expression}

An enzyme-linked antibody binding assay (Cooper et al., 1999) was used to determine the level of $\mathrm{nAChR}$ expressed on the surface of cells transfected with the $\alpha 4 \beta 2, \alpha 4 \beta 2 \chi$, and $\alpha 4 \chi \beta 2$ subunit combinations. In agreement with previous findings (Cooper et al., 1999), coexpression of $\alpha 4$ with $\beta 2 \chi$, rather than $\beta 2$, did not significantly increase cell-surface expression of the $\alpha 4$ subunit, but coexpression of $\beta 2$ with $\alpha 4 \chi$, rather than $\alpha 4$, caused a significant upregulation in the level of $\beta 2$ expressed on the cell surface (8.5 \pm 1.9 -fold; $n=4 ; p<0.001)$ (Fig. $2 A)$.

Experiments were performed to examine the effect of chronic nicotine treatment $(10 \mu \mathrm{M}, 24 \mathrm{hr})$ on levels of cell-surface receptor in cells expressing $\alpha 4 \beta 2, \alpha 4 \beta 2 \chi$, and $\alpha 4 \chi \beta 2$ subunit combinations (Fig. $2 A$ ). Because $\alpha 4 \chi$ and $\beta 2 \chi$ are expressed on the cell surface as homomeric complexes (Cooper et al., 1999), surface levels of $\alpha 4 \chi \beta 2$ were assayed by mAb270 binding, and levels of $\alpha 4 \beta 2 \chi$ were assayed by mAb299 binding, thus ensuring that only assembled cell-surface complexes were detected. Surface levels of $\alpha 4 \beta 2$ were assayed separately with both mAb270 and mAb299. Replotting of these data (Fig. $2 B$ ) emphasizes that, as was found for radioligand binding (Fig. 1), the extent of nicotine-induced upregulation of cell-surface receptor is influenced strongly by subunit composition. Chronic nicotine treatment caused a significant upregulation of cell-surface $\alpha 4 \beta 2$ (3.3 \pm 0.2 -fold, $n=4, p<$ 0.01 , when assayed by mAb299; $3.8 \pm 0.7$-fold, $n=4, p<0.01$, when assayed by mAb270) and of $\alpha 4 \beta 2 \chi(1.2 \pm 0.1$-fold; $n=4$; $p=0.05)$, but in contrast, nicotine did not significantly increase the level of cell-surface expression of either $\alpha 4 \chi \beta 2$ or $5 \mathrm{HT}_{3 \mathrm{~A}}$ (Fig. 2B).

\section{Determination of total subunit protein level by immunoblotting}

Previous immunoblotting studies that examined the level of total subunit protein in transfected cells have shown that subunit chimeras (such as $\alpha 4 \chi$ ) and nonchimeric subunits (such as $\alpha 4$ ) are expressed at similar levels (Cooper et al., 1999). The same approach was used here to examine the effect of chronic nicotine treatment on levels of total subunit protein. Immunoblotting with mAb299, an antibody raised against an extracellular epitope on $\alpha 4$ (Whiting and Lindstrom, 1988), indicates that chronic nicotine treatment has no significant effect on the level of total $\alpha 4$ or $\alpha 4 \chi$ subunit protein (Fig. 3A). This experiment also confirms our previous finding (Cooper et al., 1999) that similar levels of total $\alpha 4$ and $\alpha 4 \chi$ subunit protein are expressed in transfected TSA201 cells.

Although mAb270, an antibody raised against an extracellular epitope of $\beta 2$ (Whiting and Lindstrom, 1987), was used successfully to detect cell surface-expressed subunit (Fig. 2), it was not possible to use this antibody to detect $\beta 2$ subunit protein on immunoblots, presumably because it recognizes a conformation- 

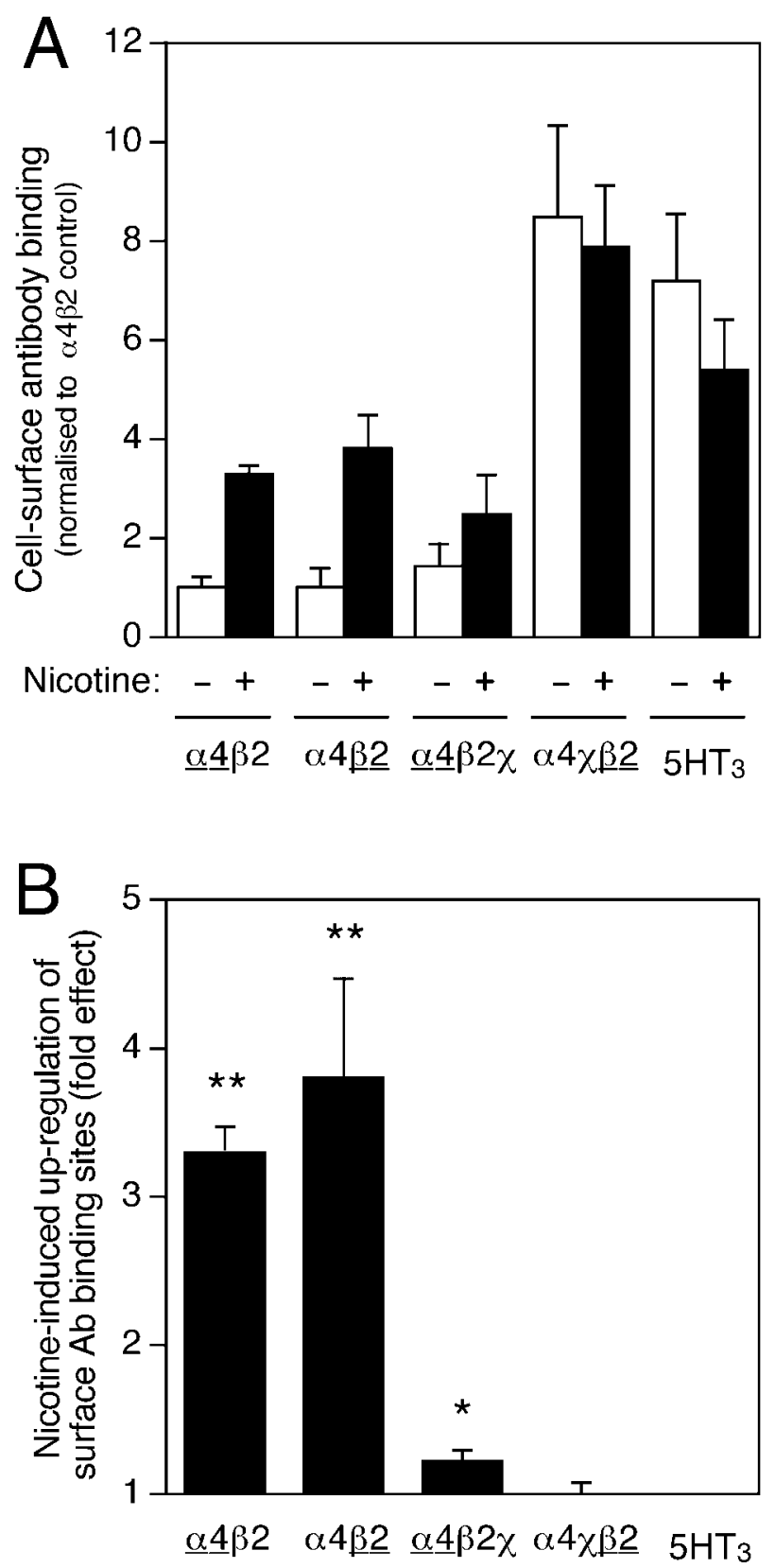

Figure 2. Influence of chronic nicotine treatment and subunit composition on cell-surface antibody binding. $A$, Surface antibody binding to intact cell monolayers was determined with mAb270 (anti- $\beta 2$ ), mAb299 (anti- $\alpha 4$ ), or pAb120 (anti-5HT ${ }_{3 \mathrm{~A}}$ ) using an enzyme-linked antibody binding assay (see Materials and Methods). Surface levels of $\alpha 4 \chi \beta 2$ were assayed by mAb270 binding, and levels of $\alpha 4 \beta 2 \chi$ were assayed by mAb299 binding, thus ensuring that only assembled cell-surface complexes were detected (neither $\alpha 4$ nor $\beta 2$ is expressed on the cell surface when expressed individually). Surface levels of $\alpha 4 \beta 2$ were assayed separately with both $\mathrm{mAb} 270$ and $\mathrm{mAb} 299$. For all subunit combinations $(\alpha 4 \beta 2$, $\alpha 4 \beta 2 \chi, \alpha 4 \chi \beta 2$, and $5 \mathrm{HT}_{3 \mathrm{~A}}$ ), antibody binding was determined in cells that had been grown in the absence (white bars) or presence (black bars) of nicotine $(10 \mu \mathrm{M}, 24 \mathrm{hr})$. The background signal from mock-transfected coverslips has been subtracted. Data are the means \pm SEM of four independent experiments and have been normalized to the level of surface antibody binding determined with $\alpha 4 \beta 2$ in the absence of nicotine. $B$, Data have been replotted to show the extent of nicotine-induced upregulation of antibody binding for each subunit combination. Where two subunits are coexpressed, the subunit assayed by mAb binding is underlined. Statistical significance of the results, determined by two-tailed Student's $t$ test, is indicated $\left({ }^{*} p=0.05 ;{ }^{* *} p<0.01\right)$.
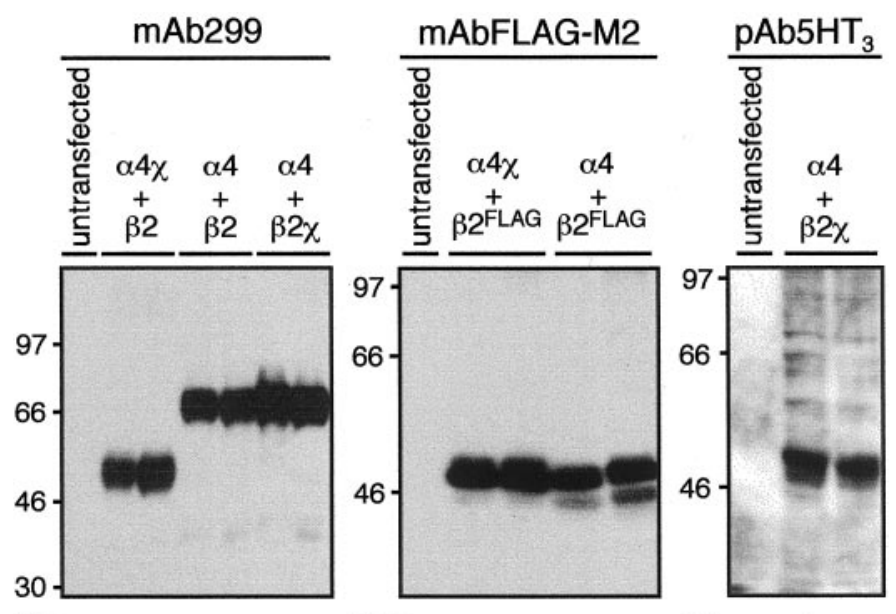

Nic: -+-+++

Nic: -

Figure 3. Influence of chronic nicotine treatment and subunit composition on total subunit protein levels determined by immunoblotting. Total cellular protein $(150 \mu \mathrm{g})$ from TSA201 cells transfected with various subunit combinations and grown in the presence or absence of nicotine $(10 \mu \mathrm{M}, 24 \mathrm{hr}$ ) was separated by SDS-PAGE and immunoblotted with mAb299, which recognizes $\alpha 4$ and $\alpha 4 \chi$, mAbFLAG-M2, which recognizes epitope-tagged $\beta 2^{\mathrm{FLAG}}$, or $\mathrm{pAb} 5 \mathrm{HT}_{3}$, which recognizes $\beta 2 \chi$. Specific immunoreactive bands (absent from mock-transfected control cells) were detected for $\alpha 4(\sim 70 \mathrm{kDa}), \alpha 4 \chi(\sim 55 \mathrm{kDa}), \beta 2^{\mathrm{FLAG}}(\sim 55 \mathrm{kDa})$, and $\beta 2 \chi(\sim 55 \mathrm{kDa})$. The positions of protein molecular weight markers are shown.

sensitive epitope. Therefore, to compare the levels of total $\beta 2$ subunit expressed in the presence and absence of chronic nicotine treatment, mAbFLAG-M2 (Hopp et al., 1988) was used to detect an epitope-tagged $\beta 2$ construct $\left(\beta 2^{\text {FLAG }}\right)$ expressed in TSA201 cells (Fig. $3 B$ ). The level of $\beta 2 \chi$ subunit protein expressed in the presence and absence of chronic nicotine treatment was examined by immunoblotting with $\mathrm{pAb} 5 \mathrm{HT}_{3}$, a polyclonal antibody raised against the intracellular loop region of $5 \mathrm{HT}_{3 \mathrm{~A}}$ (Turton et al., 1993) (Fig. 3C). Immunoblotting with mAbFLAG-M2 and $\mathrm{pAb}_{5} \mathrm{HT}_{3}$ indicates that chronic nicotine treatment does not upregulate the level of total $\beta 2$ or $\beta 2 \chi$ subunit protein. It appears, therefore, that chronic nicotine treatment does not upregulate levels of total protein for any of the subunits examined $(\alpha 4, \alpha 4 \chi$, $\beta 2$, and $\beta 2 \chi$ ).

The results described above suggest that although chronic nicotine treatment and the expression of subunit chimeras can upregulate the level of cell-surface receptor and the number of radioligand binding sites, they do not upregulate the level of total subunit protein. The following series of experiments was aimed at investigating the effect of chronic nicotine treatment and chimeric subunits on the subcellular distribution of radioligand binding sites and of subunit protein.

\section{Subcellular distribution of nicotinic binding sites}

The proportion of nicotinic agonist binding sites expressed at the cell surface of transfected cells was determined by examining the level of radioligand binding with $\left[{ }^{3} \mathrm{H}\right] \mathrm{MCC}$, a membraneimpermeant nicotinic ligand that binds to $\alpha 4 \beta 2 \mathrm{nAChRs}$ with high affinity $\left(K_{\mathrm{d}}=2.9 \pm 0.4 \mathrm{nM}\right)$ (Lansdell and Millar, 2000). This is a more direct approach than the method used previously to compare surface and total specific binding sites that used unlabeled impermeant ligands to selectively block surface binding sites for the membrane-permeant radioligand $\left[{ }^{3} \mathrm{H}\right]$ epibatidine (Whiteaker et al., 1998). The $B_{\max }$ value determined for $\left[{ }^{3} \mathrm{H}\right] \mathrm{MCC}$ 
binding to $\alpha 4 \beta 2$ cell homogenates $(0.15 \pm 0.05 \mathrm{pmol} / \mathrm{mg}$ protein; $n=7$ ) is not significantly different from the value determined with $\left[{ }^{3} \mathrm{H}\right]$ epibatidine. In Figure $4 A$, data determined for both cellsurface $\left[{ }^{3} \mathrm{H}\right] \mathrm{MCC}$ binding and total specific $\left[{ }^{3} \mathrm{H}\right] \mathrm{MCC}$ binding for three subunit combinations $(\alpha 4 \beta 2, \alpha 4 \beta 2 \chi$, and $\alpha 4 \chi \beta 2)$ have been used to calculate the proportion of binding sites on the cell surface (as a percentage of total specific binding). Although only $24.3 \pm$ $2.2 \%(n=6)$ of $\alpha 4 \beta 2$ binding sites were detected on the cell surface, a significantly higher proportion of the total specific binding sites was expressed on the cell surface for $\alpha 4 \beta 2 \chi$ and $\alpha 4 \chi \beta 2$ $(44.3 \pm 8.7$ and $91.1 \pm 6.2 \%$, respectively; $n=4)$.

The influence of chronic nicotine treatment on the subcellular distribution of nicotinic radioligand binding sites was examined for $\alpha 4 \beta 2, \alpha 4 \beta 2 \chi$, and $\alpha 4 \chi \beta 2$ subunit combinations (Fig. 4). In cells transfected with $\alpha 4 \beta 2$, the proportion of cell-surface $\left[{ }^{3} \mathrm{H}\right] \mathrm{MCC}$ binding sites increased (from $24.3 \pm 2.2 \%$ ) to $46.6 \pm$ $3.9 \%$ after chronic nicotine treatment. Levels of total specific binding to $\alpha 4 \beta 2$ were upregulated to a similar extent by nicotine treatment, whether assayed by $\left[{ }^{3} \mathrm{H}\right] \mathrm{MCC}(4.0 \pm 1.0$-fold; $n=6)$ or by $\left[{ }^{3} \mathrm{H}\right]$ epibatidine $(5.1 \pm 0.7$-fold; $n=4)$ (Fig. 1$)$. The proportion of $\alpha 4 \beta 2 \chi$ cell-surface binding sites increased (from $44.3 \pm 8.7 \%$ ) to $63.4 \pm 8.1 \%$. In contrast, no significant difference was seen in the proportion of cell-surface $\alpha 4 \chi \beta 2$ binding sites $(91.1 \pm 6.2 \%$ in untreated cells and $88.1 \pm 8.4 \%$ in nicotinetreated cells). The extent of nicotine-induced upregulation of cell-surface binding sites is emphasized by replotting data as fold increase in surface binding (Fig. $4 B$ ). For $\alpha 4 \beta 2$ and $\alpha 4 \beta 2 \chi$, the fold increase in the percentage of cell-surface binding sites after nicotine treatment was $1.9 \pm 0.2$-fold $(n=6 ; p<0.01)$ and $1.5 \pm$ 0.3 -fold $(n=4 ; p=0.067)$, respectively. The influence of nicotine treatment and coexpressed subunits on the proportion of radioligand binding sites on the cell surface is summarized in Table 1.

Because we assume that subunits on the cell surface are folded correctly into their "mature" conformation, it would be reasonable to expect that the absolute (fold) increase in cell-surface receptor caused by nicotine treatment would be similar, whether assayed by antibody or by radioligand binding. As was illustrated in Figure $2 B$, chronic nicotine treatment produced a three- to fourfold increase in the amount of $\alpha 4 \beta 2$ on the cell surface and a 1.2-fold increase in coassembled $\alpha 4 \beta 2 \chi$ complexes on the cell surface. The absolute increase in cell-surface $\left[{ }^{3} \mathrm{H}\right] \mathrm{MCC}$ binding caused by chronic nicotine treatment was $7.3 \pm 2.4$-fold $(n=4)$ for $\alpha 4 \beta 2$ and $1.6 \pm 0.5$-fold $(n=4)$ for $\alpha 4 \beta 2 \chi$. There was considerable variability between experiments in the fold increase in surface $\left[{ }^{3} \mathrm{H}\right] \mathrm{MCC}$ binding to $\alpha 4 \beta 2$ that is probably attributable to the relatively large experiment-to-experiment variability in the (low) basal levels of $\left[{ }^{3} \mathrm{H}\right] \mathrm{MCC}$ binding in cells expressing $\alpha 4 \beta 2$ nAChRs. As a consequence, the nicotine-induced increase in cell-surface $\left[{ }^{3} \mathrm{H}\right] \mathrm{MCC}$ binding in cells expressing $\alpha 4 \beta 2 \mathrm{nAChRs}$ is not significantly different from the increase in surface receptor assayed by mAb binding. Despite the experiment-to-experiment variability in the absolute increase in $\left[{ }^{3} \mathrm{H}\right] \mathrm{MCC}$ binding, a very consistent and reproducible increase was observed in the proportion of total $\alpha 4 \beta 2 \mathrm{nAChR}$ on the cell surface (assayed by $\left[{ }^{3} \mathrm{H}\right] \mathrm{MCC}$ binding) (see data presented in Table 1).

\section{Influence of nicotine and subunit composition on total subunit levels}

The cell-surface antibody binding data presented earlier (Fig. 2) indicates that chronic nicotine causes an upregulation in the level of cell-surface $\alpha 4 \beta 2$ and $\alpha 4 \beta 2 \chi$ receptor in transfected cells. To determine the effect of chronic nicotine treatment on the propor-
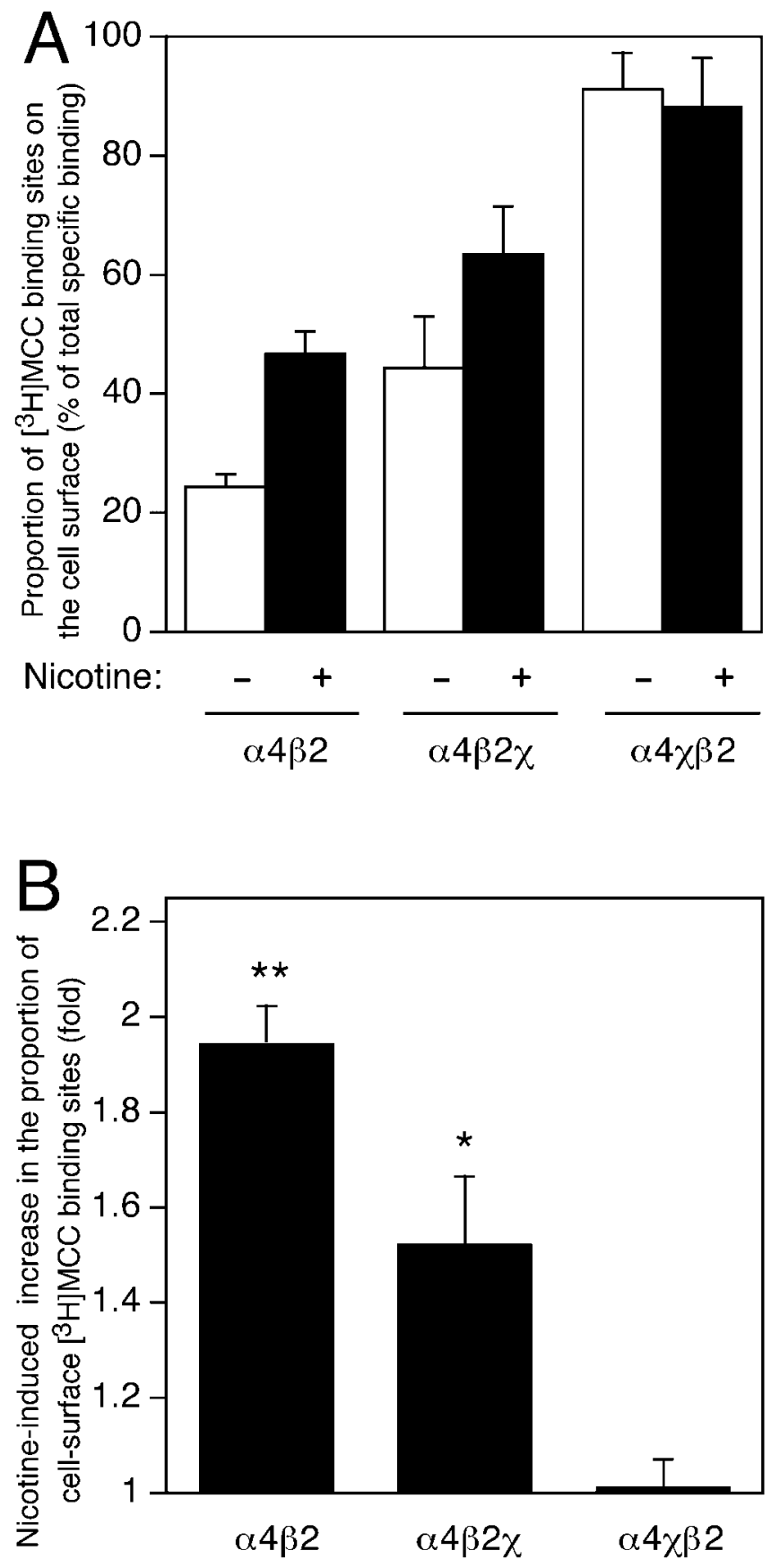

Figure 4. Influence of chronic nicotine treatment and subunit composition on the proportion of radioligand binding sites expressed on the cell surface. $A$, Specific binding of the membrane-impermeant nicotinic radioligand $\left[{ }^{3} \mathrm{H}\right] \mathrm{MCC}$ was determined for intact and homogenized cells in the absence (white bars) and presence (black bars) of nicotine $(10 \mu \mathrm{M}, 24$ $\mathrm{hr}$ ). Data are presented as the proportion of binding sites on the cell surface (as a percentage of total specific binding). Data are means \pm SEM of four to six independent experiments using a saturating concentration of ligand $(25 \mathrm{~nm}) . B$, Data have been replotted to show the extent of nicotine-induced upregulation of cell-surface radioligand binding for each subunit combination. Statistical significance of the results, determined by two-tailed Student's $t$ test, is indicated $\left(* p=0.067 ;{ }^{* *} p<0.01\right)$.

tion of total subunit protein on the cell surface, the level of antibody (mAb270 and mAb299) binding was examined in both intact and permeabilized cell monolayers. It should be borne in mind that what is being measured in these experiments is not 
Table 1. Influence of chronic nicotine and subunit chimeras on cell-surface expression

\begin{tabular}{|c|c|c|c|c|}
\hline \multirow{2}{*}{$\begin{array}{l}\text { Cotransfected } \\
\text { subunits }\end{array}$} & \multicolumn{2}{|c|}{$\begin{array}{l}\text { Cell-surface radioligand binding (\% of } \\
\text { total specific binding) }\end{array}$} & \multicolumn{2}{|c|}{ Cell-surface antibody binding (\% of total mAb binding) ${ }^{a}$} \\
\hline & - Nicotine & + Nicotine & - Nicotine & + Nicotine \\
\hline \multirow[t]{2}{*}{$\alpha 4+\beta 2$} & $24.3 \pm 2.2$ & $46.6 \pm 3.9$ & $2.1 \pm 0.7(\alpha 4)$ & $8.5 \pm 2.0(\alpha 4)$ \\
\hline & & & $12.2 \pm 2.1(\beta 2)$ & $17.7 \pm 4.5(\beta 2)$ \\
\hline \multirow[t]{2}{*}{$\alpha 4+\beta 2 \chi$} & $44.3 \pm 8.7$ & $63.4 \pm 8.1$ & $3.2 \pm 0.8(\alpha 4)$ & $6.5 \pm 1.5(\alpha 4)$ \\
\hline & & & $60.1 \pm 5.9(\beta 2 \chi)$ & $25.4 \pm 2.6(\beta 2 \chi)$ \\
\hline \multirow[t]{2}{*}{$\alpha 4 \chi+\beta 2$} & $91.1 \pm 6.2$ & $88.1 \pm 8.4$ & $55.7 \pm 3.9(\alpha 4 \chi)$ & $63.0 \pm 10.9(\alpha 4 \chi)$ \\
\hline & & & $90.5 \pm 4.6(\beta 2)$ & $93.0 \pm 4.4(\beta 2)$ \\
\hline
\end{tabular}

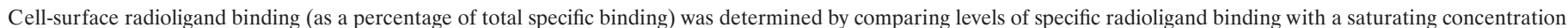

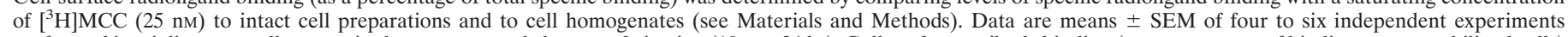

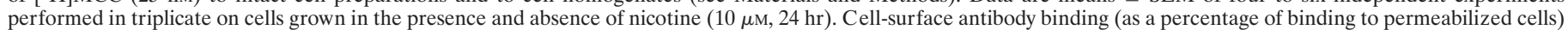

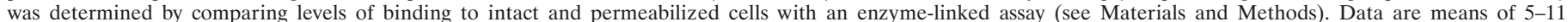

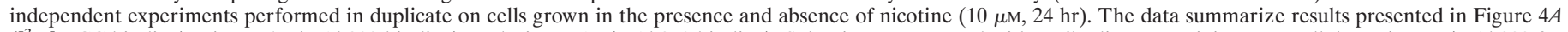

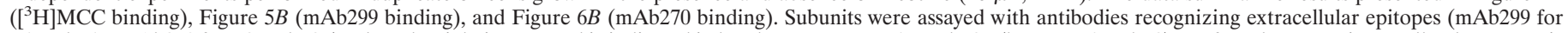

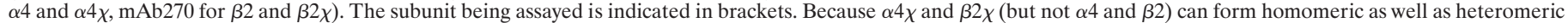
cell-surface complexes (Cooper et al. 1999), cell-surface antibody binding with mAbs targeting $\alpha 4 \chi$ and $\beta 2 \chi$ will detect a heterogeneous receptor population.

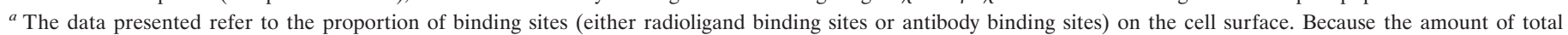

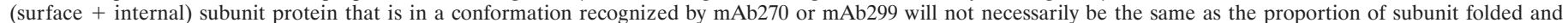

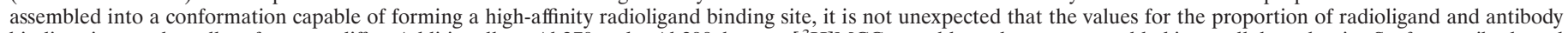

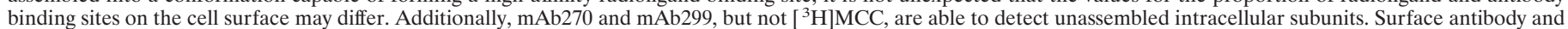

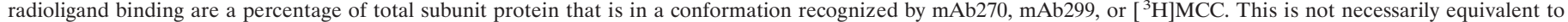
the number of binding sites (radioligand or antibody) located on the cell surface as a percentage of total subunit protein in all conformations.

necessarily the proportion of total subunit protein that is expressed on the cell surface but rather the proportion of subunit protein recognized by either mAb270 or mAb299 (i.e., the proportion of subunit protein folded into a conformation recognized by these antibodies). As mentioned earlier, mAb270 is strongly conformationally sensitive (it does not recognize $\beta 2$ after SDS denaturation), and although mAb299 does recognize SDSdenatured $\alpha 4$ subunit, suggesting that it recognizes a linear epitope, the mAb299 epitope will be masked if the subunit adopts a conformation in which the epitope is buried or inaccessible.

As can be seen in Figure $5 A$, the level of $\alpha 4 \chi$ protein detected in permeabilized cells was significantly higher $(4.2 \pm 0.5$-fold; $n=$ $7 ; p<0.001)$ than that of $\alpha 4$. This is in contrast to immunoblotting data (Fig. 3A) and suggests that, compared with the $\alpha 4$ subunit, a greater proportion of total $\alpha 4 \chi$ subunit protein is folded into a conformation recognized by mAb299. The $\beta 2$ subunit appears to have a dominant negative effect when coexpressed with $\alpha 4 \chi$, illustrated by a small but consistent (and significant) reduction in the level of mAb299 binding to permeabilized cells when $\alpha 4 \chi$ is coexpressed with the $\beta 2$ subunit $(26 \pm 3.5 \%$ decrease; $n=4 ; p<0.02)$. There is no change in mAb299 binding to $\alpha 4$, whether $\alpha 4$ is expressed alone or with $\beta 2$ or with $\beta 2 \chi$ (Fig. $5 A$ ). Examination of mAb270 binding to transfected cells (Fig. 6) reveals several interesting phenomena. In the absence of nicotine, the level of total mAb270 binding to cells transfected with $\beta 2 \chi$ alone is significantly higher $(4.3 \pm 0.2$-fold; $n=3 ; p<0.001)$ than to those transfected with $\beta 2$ alone. Significantly less $\beta 2 \chi$ is detected when $\beta 2 \chi$ is coexpressed with $\alpha 4$ (mAb270 binding is reduced by $50.9 \pm 4.5 \% ; n=3 ; p<0.01$ ). Thus, $\alpha 4$ exerts a strongly dominant negative effect on mAb270 binding (when coexpressed with $\beta 2 \chi$ ). There is no change in mAb270 binding to $\beta 2$, whether $\beta 2$ is expressed alone or with $\beta 2$; however, mAb270 detects significantly higher levels of $\beta 2$ subunit $(5.4 \pm 0.7$ fold; $n=5 ; p<0.001)$ in permeabilized cells when $\beta 2$ is coexpressed with $\alpha 4 \chi$ (Fig. 6A). Hence, although both $\alpha 4 \chi$ and $\beta 2 \chi$ yield high levels of mAb299/mAb270 binding sites when expressed alone, antibody binding to both chimeric subunits is reduced by coexpression of wild-type ( $\alpha 4$ or $\beta 2$ ) subunits.
Chronic nicotine treatment does not have a significant effect on the level of total mAb299 binding to $\alpha 4$ or $\alpha 4 \chi$ in pemeabilized cells (Fig. $5 A$ ). Similarly, there was no effect of nicotine treatment on the level of $\beta 2 \chi$, when expressed alone or when coexpressed with either $\alpha 4$ or $\alpha 4 \chi$ (Fig. $6 A$ ). However, nicotine treatment of $\alpha 4 \beta 2$-transfected cells caused a significant increase $(2.3 \pm 0.1$ fold, $n=9$; $p<0.001)$ in the level of $\beta 2$ subunit detected in permeabilized cells (Fig. 6A). These findings indicate that the amount of total $\beta 2$ subunit protein folded into a conformation recognized by mAb270 is influenced both by coassembled partner subunits (e.g., $\alpha 4$ or $\alpha 4 \chi$ ) and by chronic nicotine treatment (e.g., when coexpressed with $\alpha 4$ ).

To confirm that the discrepancy between antibody-binding data derived from studies with permeabilized cells (Figs. 5A, 6A) and from immunoblotting data (Fig. 3 ) is not an artifact caused by the permeabilized cell binding assay, the experiment was repeated with $\beta 2^{\text {FLAG }}$ and assayed with mAbFLAG-M2 (which recognizes a linear epitope tag). In contrast to earlier results with mAb270 binding to $\beta 2$ (Fig. 6), no significant difference was seen in the level of mAbFLAG-M2 binding to $\beta 2^{\mathrm{FLAG}}$, either after chronic nicotine treatment or as a consequence of coexpression of $\beta 2^{\text {FLAG }}$ with $\alpha 4 \chi$ rather than $\alpha 4$ (Fig. 7). In agreement with the earlier data (Fig. 6), the influence of subunit composition and nicotine treatment on $\alpha 4 \beta 2^{\text {FLAG }}$ was observed with mAb270 binding to $\beta 2^{\text {FLAG }}$ (Fig. 7). Together with the immunoblotting data (Fig. 3), this provides strong support for our conclusion that although factors such as nicotine treatment and coassembled subunit partners do not influence levels of total $\beta 2$ subunit protein, they do influence the proportion of subunit protein folded into a conformation recognized by conformation-sensitive antibodies (such as mAb270) and by nicotinic ligands (such as $\left[{ }^{3} \mathrm{H}\right]$ epibatidine and $\left.\left[{ }^{3} \mathrm{H}\right] \mathrm{MCC}\right)$. Experiments were also performed to confirm that nicotine-induced upregulation of cellsurface receptor could be detected by mAbFLAG-M2 binding to cells transfected with $\beta 2^{\text {FLAG }}$. Chronic nicotine treatment of cells expressing $\alpha 4 \beta 2^{\text {FLAG }}$ resulted in the upregulation of cell-surface mAbFLAG-M2 binding $(2.7 \pm 0.3$-fold; $n=3)$. This is similar to the level of receptor upregulation detected in experiments in 

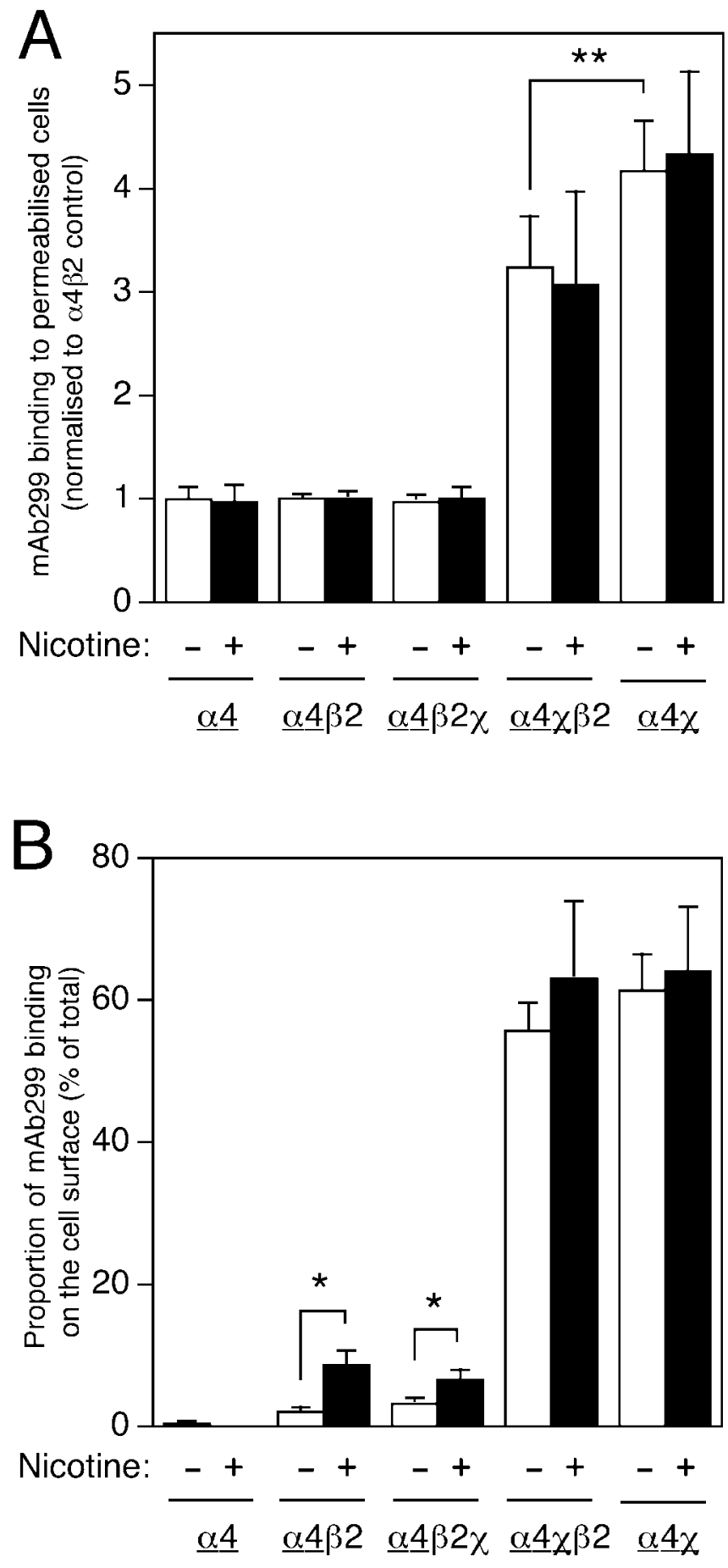

Figure 5. Influence of chronic nicotine treatment and subunit composition on subcellular distribution of $\alpha 4$ and $\alpha 4 \chi$ subunits. Transfected TSA201 cells, grown on coverslips, were labeled with mAb299 (specific for $\alpha 4$ and $\alpha 4 \chi$ subunits) either after membrane permeabilization or as intact cell monolayers. Data are presented as total antibody binding to permeabilized cells $(A)$ and as the proportion of antibody binding sites on the cell surface $(B)$. The level of mAb299 binding was determined in an enzyme-linked assay (see Materials and Methods). For all subunit combinations, mAb299 binding was determined in cells that had been grown in the absence (white bars) or presence (black bars) of nicotine (10 $\mu \mathrm{M}, 24$ $\mathrm{hr}$ ). Data are the means of five to nine independent experiments, each performed in duplicate, and have been normalized to the level of mAb299 binding determined for permeabilized cells transfected with $\alpha 4 \beta 2$ in the absence of nicotine. The background signal from mock-transfected coverslips has been subtracted. $B$, The proportion of mAb299 binding which cells transfected with $\alpha 4 \beta 2$ were assayed by mAb270 binding (Fig. 2), and argues that, when expressed on the cell surface, most if not all of the assembled $\beta 2$ subunit is in a conformation recognized by the conformationally sensitive antibody mAb270.

\section{Influence of nicotine and subunit composition on nAChR subunit distribution}

Data from antibody binding experiments conducted with intact and permeabilized cells were used to determine the proportion of total folded subunit protein (i.e., total subunit protein recognized by $\mathrm{mAb} 270$ or mAb299) that is expressed on the cell surface (Figs. $5 B, 6 B$ ). It is apparent that chronic nicotine treatment upregulates the proportion of $\alpha 4$ subunit on the cell surface when it is coexpressed with either $\beta 2$ (from $2.1 \pm 0.7$ to $8.5 \pm 2.0 \% ; n=$ $3 ; p<0.05)$ or $\beta 2 \chi($ from $3.2 \pm 0.8$ to $6.5 \pm 1.5 \% ; n=3 ; p<0.05)$ (Fig. 5B). A much higher proportion of $\alpha 4 \chi$ is expressed on the cell surface in all combinations examined $(\sim 60 \%)$ and is unaffected by chronic nicotine treatment (Fig. $5 B$ ).

Although a relatively small proportion of $\beta 2$ is expressed on the cell surface when it is coexpressed with $\alpha 4, \sim 90 \%$ of $\beta 2$ is detected on the cell surface when coexpressed with $\alpha 4 \chi$ (Fig. 6B). Particularly striking is the finding that coexpression of $\alpha 4$ substantially reduces the proportion of $\beta 2 \chi$ expressed on the cell surface (from $78.2 \pm 3.1$ to $60.1 \pm 5.9 \% ; n=3 ; p<0.02$ ) and that this is reduced yet further by chronic nicotine treatment (to $25.4 \pm 2.6 \% ; n=3 ; p<0.05$ ) (Fig. 6B). The influence of both nicotine treatment and coexpressed subunits on the proportion of total subunit detected on the cell surface by antibody binding is summarized in Table 1.

\section{DISCUSSION}

It has been reported previously that relatively low levels of $\alpha 4 \beta 2$ $\mathrm{nAChR}$ are expressed on the cell surface of transfected cell lines, but coexpression of either $\alpha 4$ or $\beta 2$ with subunit chimeras $(\alpha 4 \chi$ and $\beta 2 \chi$ ) containing the $\mathrm{C}$-terminal domain of the $5 \mathrm{HT}_{3 \mathrm{~A}}$ subunit can upregulate levels of $\alpha 4$ and $\beta 2$ on the cell surface (Cooper et al., 1999). Data presented in the current study allow us to interpret such observations in terms of subunit conformation and subcellular distribution.

Neither $\alpha 4$ nor $\beta 2$ is expressed at detectable levels on the cell surface when expressed alone (Cooper et al., 1999; Harkness and Millar, 2001). In cells cotransfected with $\alpha 4$ and $\beta 2, \sim 10 \%$ or less of total $\alpha 4$ or $\beta 2$ subunit protein (recognized by mAb299 or $\mathrm{mAb} 270$, respectively) is on the cell surface. However, coexpression of $\beta 2$ with $\alpha 4 \chi$ (rather than with $\alpha 4$ ) results in a dramatic upregulation of cell-surface levels of $\beta 2$ ( $~ 8.5$-fold) (Fig. 2), corresponding to $90 \%$ of total $\beta 2$ subunit protein recognized by mAb270 (Fig. 6). Of the relatively low number of radioligand binding sites detected for $\alpha 4 \beta 2$ in the absence of nicotine, $\sim 25 \%$ are on the cell surface (Fig. 4). In cells transfected with $\alpha 4 \beta 2 \chi$, there are approximately five times more radioligand binding sites, and of these, $\sim 50 \%$ are expressed on the cell surface (Fig. 4). In

\section{$\leftarrow$}

detected on the cell surface for each subunit combination has been determined from parallel experiments performed on permeabilized and intact cell monolayers. Because $\alpha 4 \chi$ can form homomeric (as well as heteromeric) cell-surface complexes (Cooper et al., 1999), mAb299 would be expected to detect a heterogeneous population of cell-surface complexes in cells cotransfected with $\alpha 4 \chi+\beta 2$. To emphasize which subunit is being assayed by mAb299 binding ( $\alpha 4$ or $\alpha 4 \chi$, rather than $\beta 2$ or $\beta 2 \mathrm{x}$ ), the appropriate subunit is underlined. Significant differences, determined by two-tailed Student's $t$ test, are indicated (*p<0.05; ** $p<0.02$ ). 

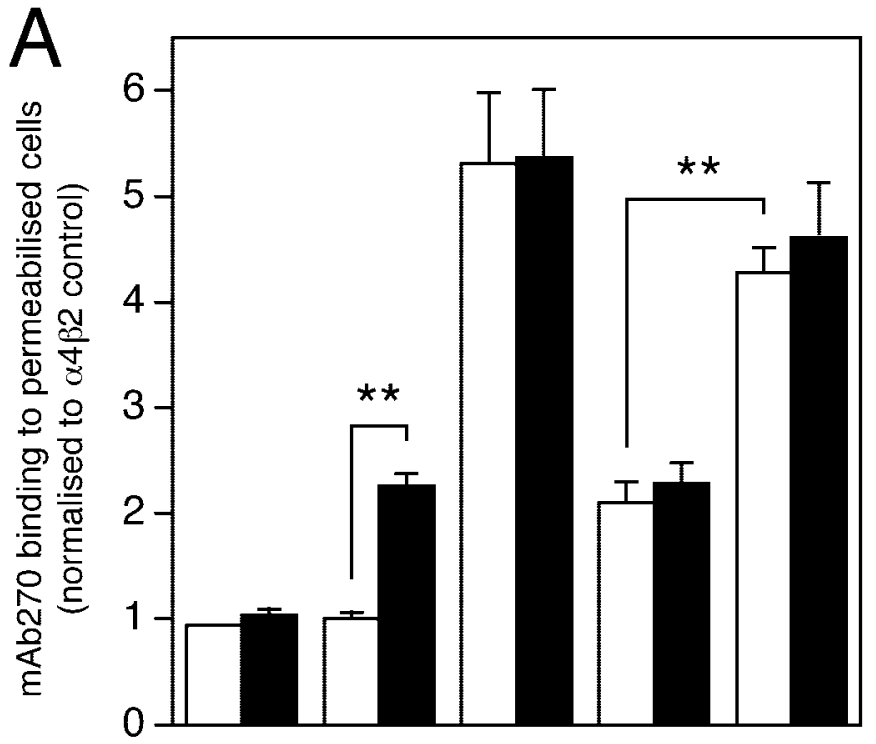

Nicotine:

$$
\frac{-+}{\underline{\beta 2}} \frac{-+}{\alpha 4 \underline{\beta 2}} \frac{-+}{\alpha 4 \chi \underline{\beta 2}} \frac{-+}{\alpha 4 \underline{\beta 2} \chi} \frac{-+}{\underline{\beta 2} \chi}
$$

$\mathrm{B}$

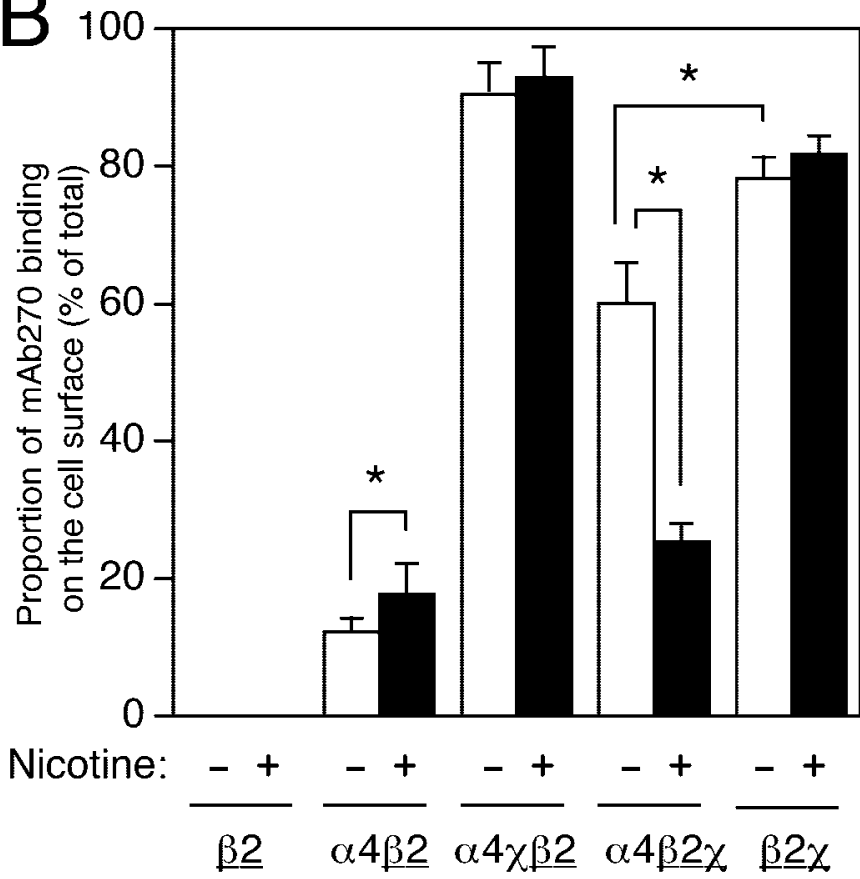

Figure 6. Influence of chronic nicotine treatment and subunit composition on subcellular distribution of $\beta 2$ and $\beta 2 \chi$ subunits. Transfected TSA201 cells, grown on coverslips, were labeled with mAb270 (specific for $\beta 2$ and $\beta 2 \chi$ subunits) either after membrane permeabilization or as intact cell monolayers. Data are presented as total antibody binding to permeabilized cells $(A)$ and as the proportion of antibody binding sites on the cell surface $(B)$. The level of mAb270 binding was determined in an enzyme-linked assay (see Materials and Methods). For all subunit combinations, mAb270 binding was determined in cells that had been grown in the absence (white bars) or presence (black bars) of nicotine (10 $\mu \mathrm{M}, 24$ hr). Data are the means of 5-11 independent experiments, each performed in duplicate, and have been normalized to the level of mAb270 binding determined with permeabilized cells transfected with $\alpha 4 \beta 2$ in the absence of nicotine. The background signal from mock-transfected

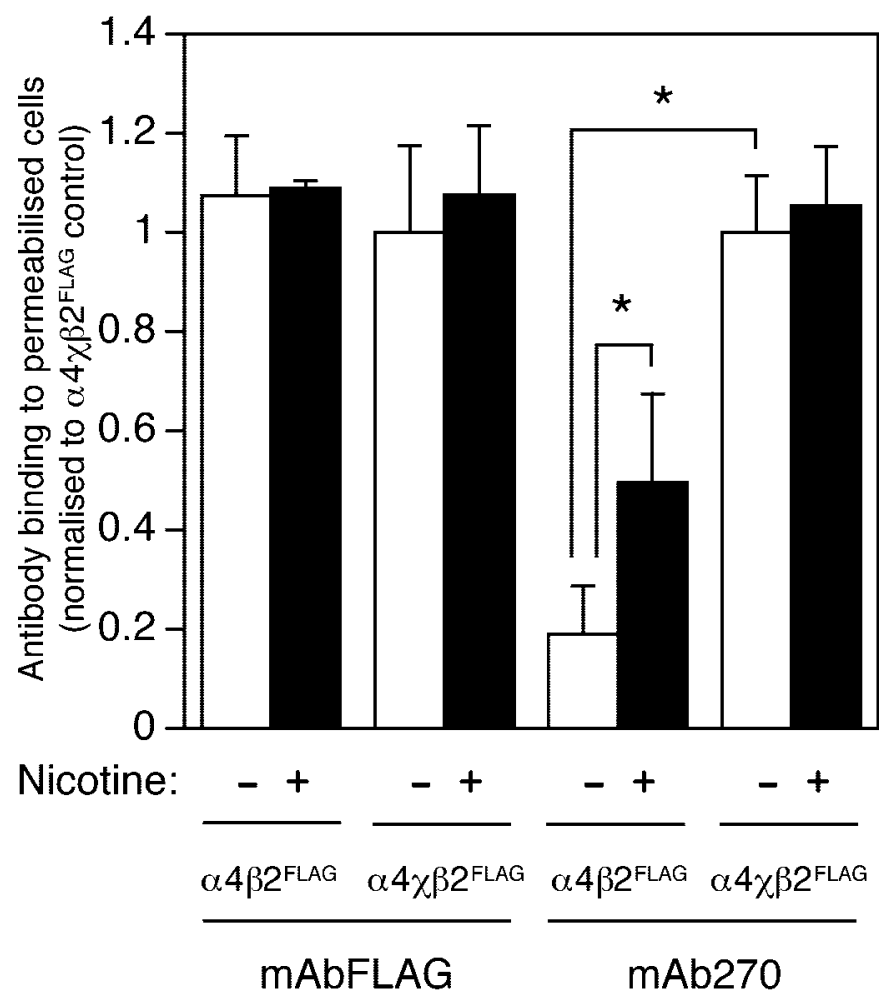

Figure 7. Influence of chronic nicotine treatment and subunit composition on levels of $\beta 2^{\text {FLAG }}$ detected in permeabilized cells. Transfected TSA201 cells, grown on coverslips, were labeled with either mAb270 or mAbFLAG-M2 (both of which recognize $\beta 2^{\mathrm{FLAG}}$ ). The level of antibody binding was determined after membrane permeabilization in an enzymelinked assay using an HRP-linked secondary antibody (see Materials and Methods). For all subunit combinations, antibody binding was determined in cells that had been grown in the absence (white bars) or presence (black bars) of nicotine $(10 \mu \mathrm{M}, 24 \mathrm{hr})$. Data are the means of two to three independent experiments, each performed in duplicate, and have been normalized to the level of binding determined with cells transfected with $\alpha 4 \chi \beta 2^{\mathrm{FLAG}}$ in the absence of nicotine. The background signal from mock-transfected coverslips has been subtracted. Significant differences, determined by two-tailed Student's $t$ test, are indicated $\left({ }^{*} p<0.05\right)$.

cells transfected with $\alpha 4 \chi \beta 2$, there are $\sim 20$ times more radioligand binding sites, of which $\sim 90 \%$ are at the cell surface (Fig. 4 ). A more dramatic effect on radioligand binding and cell-surface expression is caused by replacing $\alpha 4$ with $\alpha 4 \chi$ than by replacing $\beta 2$ with $\beta 2 \chi$ (Figs. 1,2), suggesting that the low level of binding and cell-surface expression observed for $\alpha 4 \beta 2$ is influenced primarily by the $\alpha 4$ subunit.

Immunoblotting experiments with mAb299 comparing total cellular levels of SDS-denatured $\alpha 4$ and $\alpha 4 \chi$ subunit protein indicate that when transfected alone these two subunits are expressed at similar levels (Cooper et al., 1999). In contrast, when

\footnotetext{
coverslips has been subtracted. $B$, The proportion of mAb270 binding detected on the cell surface for each subunit combination has been determined from parallel experiments performed on permeabilized and intact cell monolayers. Because $\beta 2 \chi$ can form homomeric (as well as heteromeric) cell-surface complexes (Cooper et al., 1999), mAb270 would be expected to detect a heterogeneous population of cell-surface complexes in cells cotransfected with $\alpha 4+\beta 2 \chi$. To emphasize which subunit is being assayed by mAb270 binding ( $\beta 2$ or $\beta 2 \chi$, rather than $\alpha 4$ or $\alpha 4 \chi$ ), the appropriate subunit is underlined. Significant differences, determined by two-tailed Student's $t$ test, are indicated $\left({ }^{*} p<0.05 ;{ }^{* *} p<0.01\right)$.
} 
the same antibody is used to determine total levels of $\alpha 4$ and $\alpha 4 \chi$ subunit protein in permeabilized cells (without SDS denaturation of subunits), $\alpha 4$ is detected at significantly lower levels (approximately fourfold lower) than $\alpha 4 \chi$ (Fig. $5 A$ ). This would suggest that a significant proportion of the total $\alpha 4$ subunit protein is in a conformation not recognized by mAb299, perhaps because of inappropriate subunit folding masking the mAb299 epitope.

An important aspect of the present study is the evidence that subunit folding can be influenced by the coassembled partner subunit. This was implied by our previous studies examining coassembly of chimeric $\alpha 4 \chi$ and $\beta 2 \chi$ subunits (Cooper et al., 1999; Harkness and Millar, 2001), but the current findings present more direct evidence for an influence of coassembled subunit partners on subunit conformation. Immunoblotting (Fig. 3) and antibody binding to cell monolayers (Fig. 7) with an epitopetagged $\beta 2$ subunit $\left(\beta 2^{\mathrm{FLAG}}\right)$ suggest that the level of total $\beta 2$ subunit protein is similar, whether coexpressed with $\alpha 4$ or $\alpha 4 \chi$. In contrast, in permeabilized cells, the level of total mAb270 binding to $\beta 2$ is approximately fivefold lower when it is coexpressed with $\alpha 4$ than with $\alpha 4 \chi$ (Fig. $6 A$ ). A plausible explanation for this would be that when coassembled with $\alpha 4 \chi$, a greater proportion of the total $\beta 2$ subunit protein is in a conformation recognized by mAb270. The idea that subunit conformation can be influenced by coassembly with other subunits (rather than subunits adopting their fully folded native conformation before assembly) is a feature of current models of nAChR assembly (Green and Millar, 1995; Green, 1999; Keller and Taylor, 1999) and has been proposed as a mechanism by which nAChRs and other heterooligomeric complexes achieve their appropriate subunit composition and stoichiometry via sequential addition of subunits to partially folded "assembly intermediate" complexes (Green and Claudio, 1993; Green and Millar, 1995; Green, 1999).

The dominant influence of the $\alpha 4$ subunit is illustrated further by comparing levels of mAb270 binding to $\beta 2 \chi$ when expressed alone or when coexpressed with $\alpha 4$ (Fig. 6A). Coexpression of the $\alpha 4$ subunit with $\beta 2 \chi$ reduces the amount of $\beta 2 \chi$ detected on the cell surface, suggesting that coassembly of $\alpha 4$ with $\beta 2 \chi$ causes substantial intracellular retention of the $\beta 2 \chi$ subunit. A similar dominant negative effect of $\alpha 4$ was observed for $\alpha 4$ coexpressed with the $5 \mathrm{HT}_{3 \mathrm{~A}}$ subunit (Harkness and Millar, 2001).

Immunoblotting of SDS-denatured cell extracts (Fig. 3) reveals that chronic nicotine treatment has little, if any, influence on total $\mathrm{nAChR} \alpha 4$ or $\beta 2$ subunit protein levels in transfected cells. This suggests that the observed upregulation in radioligand binding detected in cell homogenates as a consequence of chronic nicotine treatment (up to an approximately fivefold increase) (Fig. 1) is attributable to an increase in the proportion of total subunit protein that is folded and assembled into a conformation capable of generating an agonist binding site. Similarly, the observed upregulation of cell-surface $\mathrm{nAChRs}$ as a consequence of chronic nicotine treatment (up to $\sim 3.5$-fold increase) (Figs. 2, 5) reflects a greater proportion of total subunit protein expressed on the cell surface. These findings are consistent with previous studies which concluded that chronic nicotine-induced upregulation occurs by a post-translational mechanism (Peng et al., 1994; Bencherif et al., 1995; Rothhut et al., 1996).

In comparison with its effect on $\alpha 4 \beta 2$, chronic nicotine treatment caused significantly less upregulation (of either radioligand or surface antibody binding) in cells transfected with chimeric subunits, presumably reflecting the higher levels of binding and cell-surface expression for such subunit combinations in the absence of nicotine. In cells transfected with $\alpha 4 \beta 2 \chi$, nicotine caused a twofold increase in total radioligand binding (Fig. 1) and increased the proportion of radioligand binding sites expressed on the cell surface from 44 to $63 \%$ (Fig. 4). Nicotine treatment also caused a 1.2-fold increase in the proportion of $\alpha 4 \beta 2 \chi$ expressed on the cell surface. Chronic nicotine treatment had no significant effect on the proportion of cell-surface radioligand or antibody binding to $\alpha 4 \chi \beta 2$.

For most subunit combinations examined, chronic nicotine treatment does not alter total subunit protein levels estimated by antibody binding to nondenatured subunit protein in permeabilized cells (Figs. 5A,6A), the only exception being a significant twofold increase in the amount of total mAb270 binding to $\beta 2$ in cells transfected with $\alpha 4 \beta 2$ (Fig. 6). Because nicotine treatment does not substantially alter the total subunit protein level for any SDS-denatured subunits examined by immunoblotting (Fig. 3), this suggests that chronic nicotine treatment can alter the amount of $\beta 2$ subunit folded into a conformation recognized by mAb270 when $\beta 2$ is coexpressed with $\alpha 4$. In contrast, chronic nicotine treatment does not increase the amount of "correctly" folded $\beta 2$ subunit (assayed by total mAb270 binding) when it is coexpressed with $\alpha 4 \chi$. As discussed earlier, a smaller proportion of the total $\beta 2$ subunit protein is folded into a conformation recognized by mAb270 when coexpressed with $\alpha 4$ than with $\alpha 4 \chi$ (Fig. 6). Chronic nicotine does not cause an upregulation of either radioligand binding or cell-surface expression when $\beta 2$ is coexpressed with $\alpha 4 \chi$ (Figs. 1, 2, 4, 5, 6). These findings suggest that changes in subunit conformation may underlie nicotine-induced upregulation of $\alpha 4 \beta 2 \mathrm{nAChRs}$. It is also noteworthy that nicotine treatment causes a reduction in the level of $\beta 2 \chi$ subunit expressed on the cell surface when it is coexpressed with $\alpha 4$ but not when it is expressed alone (Fig. 6). This may reflect the fact that nicotine can enhance levels of $\alpha 4$ subunit folded into a conformation that can readily coassemble with $\beta 2 \chi$. Because of the dominant negative effect of $\alpha 4$ (see reduced levels of surface $\beta 2 \chi$ when coexpressed with $\alpha 4$ discussed in Results) (Fig. 6), if more "correctly folded" $\alpha 4$ were available to bind to $\beta 2 \chi$, after nicotine treatment, this would result in enhanced intracellular retention of $\beta 2 \chi$.

The influence of coexpressed subunits on subunit conformation, coassembly, and upregulation is initiated, presumably, by events occurring in the endoplasmic reticulum (where initial subunit interactions occur) (Green and Millar, 1995). Because nicotine is a membrane-permeant ligand, it is quite plausible that the consequences of chronic nicotine treatment are caused, at least in part, by its interaction with intracellular receptors. Previous studies have demonstrated, however, that $\alpha 4 \beta 2$ upregulation can be induced by exposure to membrane-impermeant ligands. This has led to the suggestion that upregulation is mediated primarily by interaction with cell-surface receptors (Whiteaker et al., 1998), possibly by changes in subunit turnover (Peng et al., 1994).

Several conclusions can be drawn from this study. Neither chronic nicotine treatment nor coexpressed subunit partners greatly affect the level of total subunit protein detected by immunoblotting (Fig. 3), but both of these factors can influence subunit folding (assayed by antibody binding to permeabilized cells) (Figs. 5A, 6A). Both chronic nicotine treatment and coexpressed subunits exert a dramatic effect on levels of radioligand binding (which reflects steady-state levels of coassembled subunits) (Fig. 1) and on the proportion of receptor expressed on the cell surface [assayed either by radioligand binding (Figs. 1, 4) or by antibody binding (Figs. 2, 5, 6)]. It is also evident that the effect of chronic 
nicotine on these parameters is strongly dependent on subunit composition.

\section{REFERENCES}

Bencherif M, Fowler K, Lukas R, Lippiello PM (1995) Mechanisms of up-regulation of neuronal nicotinic acetylcholine receptors in clonal cell lines and primary cultures of fetal rat brain. J Pharmacol Exp Ther 275:987-994.

Benwell MEM, Balfour DJK, Anderson JM (1988) Evidence that tobacco smoking increases the density of $(-)-\left[{ }^{3} \mathrm{H}\right]$ nicotine binding sites in human brain. J Neurochem 50:1243-1247.

Buisson B, Gopalakrishnan M, Arneric SP, Sullivan JP, Bertrand D (1996) Human $\alpha 4 \beta 2$ neuronal nicotinic acetylcholine receptor in HEK 293 cells: a patch-clamp study. J Neurosci 16:7880-7891.

Chen D, Dang H, Patrick JW (1998) Contributions of N-linked glycosylation to the expression of a functional $\alpha 7$-nicotinic receptor in Xenopus oocytes. J Neurochem 70:349-357.

Cooper ST, Millar NS (1997) Host cell-specific folding and assembly of the neuronal nicotinic acetylcholine receptor $\alpha 7$ subunit. J Neurochem 68:2140-2151.

Cooper ST, Millar NS (1998) Host cell-specific folding of the neuronal nicotinic receptor $\alpha 8$ subunit. J Neurochem 70:2585-2593.

Cooper ST, Harkness PC, Baker ER, Millar NS (1999) Upregulation of cell-surface $\alpha 4 \beta 2$ neuronal nicotinic receptors by lower temperature and expression of chimeric subunits. J Biol Chem 274:27145-27152.

Deneris ES, Connolly J, Boulter J, Wada E, Wada K, Swanson LW, Patrick J, Heinemann S (1988) Primary structure and expression of $\beta 2$ : a novel subunit of neuronal nicotinic acetylcholine receptors. Neuron 1:45-54.

Eiselé J-L, Bertrand S, Galzi J-L, Devillers-Thiéry A, Changeux J-P, Bertrand D (1993) Chimaeric nicotinic-serotonergic receptor combines distinct ligand binding and channel specificities. Nature 366:479-483.

Flores CM, Rogers SW, Pabreza LA, Wolfe BB, Kellar KJ (1992) A subtype of nicotinic cholinergic receptor in rat brain is composed of $\alpha 4$ and $\beta 2$ subunits and is up-regulated by chronic nicotine treatment. Mol Pharmacol 41:31-37.

Goldman D, Deneris E, Luyten W, Kochhar A, Patrick J, Heinemann S (1987) Members of a nicotinic acetylcholine receptor gene family are expressed in different regions of the mammalian central nervous system. Cell 48:965-973.

Gopalakrishnan M, Monteggia LM, Anderson DJ, Molinari EJ, PiattoniKaplan M, Donnelly-Roberts D, Arneric SP, Sullivan JP (1996) Stable expression, pharmacologic properties and regulation of the human neuronal nicotinic acetylcholine $\alpha 4 \beta 2$ receptor. J Pharmacol Exp Ther 276:289-297.

Gopalakrishnan M, Molinari EJ, Sullivan JP (1997) Regulation of human $\alpha 4 \beta 2$ neuronal nicotinic acetylcholine receptors by cholinergic channel ligands and second messenger pathways. Mol Pharmacol $52: 524-534$.

Green WN (1999) Ion channel assembly: creating structures that function. J Gen Physiol 113:163-169.

Green WN, Claudio T (1993) Acetylcholine receptor assembly: subunit folding and oligomerization occur sequentially. Cell 74:57-69.

Green WN, Millar NS (1995) Ion-channel assembly. Trends Neurosci 18:280-287.

Harkness PC, Millar NS (2001) Inefficient cell-surface expression of hybrid complexes formed by the co-assembly of neuronal nicotinic acetylcholine receptor and serotonin receptor subunits. Neuropharmacology 41:79-87.

Hopp TP, Prickett KS, Price VL, Libby RT, March CJ, Cerretti DP, Urdal DL, Conlon PJ (1988) A short polypeptide marker sequence useful for recombinant protein identification and purification. Biotechnology 6:1204-1210.

Kassner PD, Berg DK (1997) Differences in the fate of neuronal acetylcholine receptor protein expressed in neurons and stably transfected cells. J Neurobiol 33:968-982.

Ke L, Eienhour CM, Bencherif M, Lukas RJ (1998) Effects of chronic nicotine treatment on expression of diverse nicotinic acetylcholine receptor subtypes. I. Dose- and time-dependent effects of nicotine treatment. J Pharmacol Exp Ther 286:825-840.

Keller ST, Taylor P (1999) Determinants responsible for assembly of the nicotinic acetylcholine receptor. J Gen Physiol 113:171-176.
Lansdell SJ, Millar NS (2000) The influence of nicotinic receptor subunit composition on agonist, $\alpha$-bungarotoxin and insecticide (imidacloprid) binding affinity. Neuropharmacology 39:671-679.

Lansdell SJ, Schmitt B, Betz H, Sattelle DB, Millar NS (1997) Temperature-sensitive expression of Drosophila neuronal nicotinic acetylcholine receptors. J Neurochem 68:1812-1819.

Maricq AV, Peterson AS, Brake AJ, Myers RM, Julius D (1991) Primary structure and functional expression of the 5HT3 receptor, a serotoningated ion channel. Science 254:432-437.

Marks MJ, Stitzel JA, Collins AC (1985) Time course study of the effects of chronic nicotine infusion on drug response and brain function. J Pharmacol Exp Ther 235:619-628.

Marks MJ, Pauly JR, Gross SD, Deneris ES, Hermans-Borgmeyer I, Heinemann SF, Collins AC (1992) Nicotine binding and nicotine receptor subunit RNA after chronic nicotine treatment. J Neurosci 12:2765-2784.

Peng X, Gerzanich V, Anand R, Whiting PJ, Lindstrom J (1994) Nicotine-induced increase in neuronal nicotinic receptors results from a decrease in the rate of receptor turnover. Mol Pharmacol 46:523-530.

Peng X, Gerzanich V, Anand R, Wang F, Lindstrom J (1997) Chronic nicotine treatment up-regulates $\alpha 3$ and $\alpha 7$ acetylcholine receptor subtypes expressed by the human neuroblastoma cell line SH-SY5Y. Mol Pharmacol 51:776-784.

Ragozzino D, Fucile S, Giovannelli A, Grassi F, Mileo AM, Ballivet M, Alema S, Eusebi F (1997) Functional properties of neuronal nicotinic acetylcholine receptor channels expressed in transfected human cells. Eur J Neurosci 9:480-488.

Rangwala F, Drisdel RC, Rakhilin S, Ko E, Atluri P, Harkins AB, Fox AP, Salman SB, Green WN (1997) Neuronal $\alpha$-bungarotoxin receptors differ structurally from other nicotinic acetylcholine receptors. J Neurosci 17:8201-8212.

Rothhut B, Romano SJ, Vijayaraghavan S, Berg DK (1996) Posttranslational regulation of neuronal acetylcholine receptors stably expressed in a mouse fibroblast cell line. J Neurobiol 29:115-125.

Schwartz RD, Kellar KJ (1985) In vivo regulation of $\left[{ }^{3} \mathrm{H}\right]$ acetylcholine recognition sites in brain by nicotinic cholinergic drugs. J Neurochem 45:427-433.

Spier AD, Wotherspoon G, Nayak SV, Nichols RA, Priestly JV, Lummis SCR (1999) Antibodies against the extracellular domain of the 5-HT3 receptor label both native and recombinant receptors. Mol Brain Res 67:221-230.

Sweileh W, Wenberg K, Xu J, Forsayeth J, Hardy S, Loring RH (2000) Multistep expression and assembly of neuronal nicotinic receptors is both host-cell- and receptor-subtype-dependent. Mol Brain Res 75:293-302.

Turton S, Gillard NP, Stephenson FA, McKernan RM (1993) Antibodies against the 5-HT3-A receptor identify a $54 \mathrm{kDa}$ protein affinitypurified from NCB20 cells. Mol Neuropharmacol 3:167-171.

Wang F, Nelson ME, Kuryatov A, Olale F, Cooper J, Keyser K, Lindstrom J (1998) Chronic nicotine treatment up-regulates human $\alpha 3 \beta 2$ but not $\alpha 3 \beta 4$ acetylcholine receptors stably transfected in human embryonic kidney cells. J Biol Chem 273:28721-28732.

Warpman U, Friberg L, Gillespie A, Hellström-Lindahl E, Zhang X, Nordberg A (1998) Regulation of nicotinic receptor subtypes following chronic nicotinic agonist exposure in M10 and SH-SY5Y neuroblastoma cells. J Neurochem 70:2028-2037.

Whiteaker P, Sharples CGV, Wonnacott S (1998) Agonist-induced upregulation of $\alpha 4 \beta 2$ nicotinic acetylcholine receptors in M10 cells: pharmacological and spatial definition. Mol Pharmacol 53:950-962.

Whiting P, Lindstrom J (1987) Purification and characterization of a nicotinic acetylcholine receptor from rat brain. Proc Natl Acad Sci USA 84:595-599.

Whiting PJ, Lindstrom JM (1988) Characterization of bovine and human neuronal nicotinic acetylcholine receptors using monoclonal antibodies. J Neurosci 8:3395-3404.

Whiting P, Schoepfer R, Lindstrom J, Priestley T (1991) Structural and pharmacological characterization of the major brain nicotinic acetylcholine receptor subtype stably expressed in mouse fibroblasts. Mol Pharmacol 40:463-472.

Zhang X, Gong Z-H, Hellstrom-Lindahl E, Nordberg A (1994) Regulation of $\alpha 4 \beta 2$ nicotinic acetylcholine receptors in M10 cells following treatment with nicotinic agents. NeuroReport 6:313-317. 